\title{
21 \\ Pacific Diplomacy and Decolonisation in the 21st Century
}

\author{
Nic Maclellan
}

\section{Introduction}

The issue of political independence and sovereignty was a central element in the establishment of the South Pacific Forum in 1971, as four independent island nations moved out of the confines of the South Pacific Commission. Self-determination was extensively debated at the forum throughout the 1980s.

Today, well into the 21st century and the United Nations' Third International Decade for the Eradication of Colonialism, decolonisation has largely faded from the international agenda. Despite this, 16 territories remain on the United Nations' (UN) list of non-self-governing territories, including six in the Pacific: New Caledonia and French Polynesia (under French administration); Tokelau (New Zealand); Pitcairn (United Kingdom); and Guam and American Samoa (United States). Developments in these territories are monitored by the seminars, missions and annual resolutions of the UN Special Committee on Decolonisation. ${ }^{1}$

\footnotetext{
1 The generic term 'territories' is used for convenience, but these dependencies have a variety of political and constitutional structures. France describes its Pacific dependencies as 'collectivities', while Indonesian and Papua New Guinea governments bridle at the suggestion the provinces of Papua, West Papua or Bougainville require 'decolonisation'.
} 
Across the region there are also 'second order' self-determination struggles in postcolonial states that do not fall under the mandate of the UN special committee, such as Bougainville (Papua New Guinea), Rapanui (Chile), and West Papua (Indonesia).

While the UN is an important institution for setting human rights norms, it has limited enforcement capacity. The United Nations can act with the support of the administering power, as shown with New Zealand's extensive work with the UN decolonisation unit over Tokelau (Huntsman and Kelihian 2007). But Paris and Washington have long ignored UN criticism of their colonial policies, prioritising strategic interests such as US military deployments in Guam or France's control of the resources in its seven-million-square-kilometre Exclusive Economic Zone in the Pacific (Mrgudovic 2008). Moreover, the UN decolonisation unit is starved for funds and staff, and reluctant to implement an assertive agenda. ${ }^{2}$

Since the end of French nuclear testing in 1996 and the signing of New Caledonia's Noumea Accord in 1998, the Pacific Islands Forum has developed new policies on engagement with the territories. New Caledonia (1999) and French Polynesia (2004) gained forum observer status, then both upgraded to 'associate membership' at the 2006 forum meeting in Apia. Tokelau also upgraded its 2005 observer status to associate membership in 2014. Other nations remain as forum observers, including Timor-Leste (2002), Wallis and Futuna (2006) and the US dependencies of Guam, American Samoa, and the Commonwealth of the North Marianas (2011).

The policies of Australia and New Zealand (and, on occasions, other forum members) have constrained a more active role for the forum on decolonisation. Australia has increasingly backed France's regional role and proposed that territories such as New Caledonia should become full members of the forum, even before their final political status is determined. ${ }^{3}$ This significant policy shift was endorsed in the 2013 Morauta Review of the Pacific Plan for Strengthening Regional Cooperation and Integration, which argues that original forum priorities such as decolonisation and a nuclear-free Pacific 'have either been resolved or moved to other platforms for debate and determination'. ${ }^{4}$

\footnotetext{
2 For a more ambitious agenda, see Corbin (2010).

3 Interview with Parliamentary Secretary for Pacific Island Affairs Richard Marles, May 2012. See also Maclellan (2013d).

4 'The contemporary debate about regionalism has rather less intrinsic association with self-determination. Most of the issues being debated in contemporary Pacific regionalism (trade and transport, for example) are entirely within the mandate of even the non-self-determining territories to resolve, and regionalism would be better served by fully including, not excluding, such territories in the debate and in its implementation' (Pacific Plan Review 2013, p. 78).
} 
For this reason, island leaders have increasingly used other mechanisms to take diplomatic initiatives on decolonisation, such as the Melanesian Spearhead Group (MSG) and Pacific Small Island Developing States (PSIDS) ambassadors. This chapter documents two recent examples of this new Pacific diplomacy on decolonisation: the work of PSIDS for the reinscription of French Polynesia at the UN General Assembly; and the MSG's current debate on self-determination in West Papua.

These initiatives do not guarantee that independence will be achieved indeed, there are many economic, demographic and strategic barriers to decolonisation for the remaining Pacific territories. The diversity and small size of some territories is a constraint on advancing the decolonisation agenda, and significant parts of some local populations welcome immigration rights, federal grants and other benefits of territorial status (Firth 2013). In other cases Guam, West Papua, and New Caledonia - indigenous peoples have been made a minority in their own country, constraining advances through elections or referenda.

Rather than assuming a unified Pacific response to decolonisation, it is important to analyse varying reactions by regional organisations and governments. Solidarity can be trumped by countervailing influences, such as Papua New Guinea's and Fiji's relationship with Indonesia or trade ties to the European Union. As new players such as Indonesia and Timor-Leste enter Pacific regional networks, island leaders are forced to juggle more complex obligations. Fiji and Papua New Guinea (PNG) are active members of the UN Special Committee on Decolonisation, but growing ties with Asia affect their actions on decolonisation. Melanesian governments have actively supported independence movements in New Caledonia and French Polynesia, but have maintained a diplomatic silence about decolonisation in the US territories.

Canberra's strategic support for Paris and Washington is a significant roadblock to advancing the decolonisation agenda, but the following two studies of contemporary Pacific diplomacy on decolonisation also highlight the tension between principle and national interest for island governments. The first relates to the campaign to have French Polynesia reinscribed on the UN list of nonself-governing territories, in the face of French opposition. The second study looks at ongoing diplomacy through MSG and PSIDS to deal with West Papuan self-determination. 


\section{French Polynesia's Reinscription with the United Nations}

For many years, the French State has resisted international scrutiny of its colonial policies and ignored international obligations created by UN decolonisation resolutions. As noted in a November 1986 internal memo from the French Ministry of Foreign Affairs:

We have never accepted resolutions 1514 (XV) and 1541 (XV), for which we abstained ... We have never accepted the legitimacy of the Special Committee on Decolonisation, as directed by resolution 1564 (XVI), to propose the inscription of territories on the list of non-self-governing territories (Regnault 2013, pp. 69-70).

In the face of this French opposition, the Pacific Islands Forum played a crucial role in supporting the reinscription of New Caledonia on the UN list in the mid-1980s. ${ }^{5}$ The passage of UN General Assembly resolution 41/41 in December 1986 came at the height of armed conflict between the French armed forces and supporters of independence during 1984-1988.

France launched extensive diplomatic manoeuvres to ignore, delay and then derail the 1986 forum initiative, using its political and economic weight to encourage countries to abstain or oppose the resolution. Cuba, although a member of the UN Special Committee on Decolonisation and the Non-Aligned Movement, was promised a soft ride at the next UN Human Rights Commission. Tunisia and French-speaking African nations were wooed, based on solidarity to 'francophonie'. Newly independent Vanuatu was threatened with aid cuts, while Argentina was lobbied with offers of support in their dispute with United Kingdom over the Falklands/Malvinas islands (Regnault 2013, p. 99).

After years of lobbying, Australia and New Zealand only joined their island neighbours to support New Caledonia's reinscription after the election of a conservative government in Paris in 1986. Canberra and Wellington shifted policy in part due to concerns about perceived Soviet and Libyan advances in the South Pacific. Australia's then Deputy Prime Minister Lionel Bowen had stated: 'If France drags its feet too much over decolonisation, the independence movement will become increasingly radicalised and perhaps open to Soviet influence and manipulation' (The Australian 1982).

5 The list was created in 1946, but from 1947 France refused to transmit information on its overseas territories to the General Assembly, as required under Article 73e of the UN Charter. A revised UN list of territories in 1963 ignored France's Pacific dependencies, apart from the joint Anglo-French condominium of the New Hebrides. 
Since reinscription nearly 30 years ago, New Caledonia has been scrutinised by the UN Special Committee. A UN monitoring mission travelled to New Caledonia in 1999 and the governments of France and New Caledonia hosted a regional seminar of the UN Special Committee in Noumea in $2010 .{ }^{6}$ Another UN mission travelled to Noumea in March 2014, to monitor the electoral roll for New Caledonia's May 2014 provincial and congressional elections.

Despite this engagement on New Caledonia, France has continued to resist decolonisation for French Polynesia. In 2010, then French President Nicolas Sarkozy stated that France's overseas territories 'are French and will remain French'. He stressed that for French Polynesia, there is 'one red line that I will never accept should be crossed: that of independence' (Sarkozy 2010). Despite this, active Pacific diplomacy led to an historic decision on 17 May 2013, when the UN General Assembly adopted a resolution to reinscribe French Polynesia on the UN list of non-self-governing territories. ${ }^{7}$

The resolution, sponsored by Solomon Islands, Nauru and Tuvalu with support from Vanuatu, Samoa and Timor-Leste, was adopted by the UN General Assembly without a vote. It called on the French government 'as the Administering Power concerned, to intensify its dialogue with French Polynesia in order to facilitate rapid progress towards a fair and effective self-determination process, under which the terms and timelines for an act of self-determination will be agreed' ${ }^{8}$

Even as a symbolic measure, the UN resolution sparked fury in Paris. After writing to all member states in an unsuccessful bid to delay the resolution, France's UN Ambassador Gérard Araud boycotted the general assembly session. The French Ministry of Foreign Affairs raged: 'This resolution is a flagrant interference with a complete absence of respect for the democratic choice of French Polynesians and a hijacking of the decolonisation principles established by the United Nations' (Ministry of Foreign Affairs 2013).

The French government has maintained its stubborn refusal to acknowledge any role for the UN over self-determination in French Polynesia, failing to meet its obligations as an administering power. Each year, under Article 73e of the UN Charter, colonial powers are required to submit information to the United Nations relating to the economic, social and educational conditions in their

\footnotetext{
6 French Polynesian independence leader Oscar Temaru was refused entry to this UN seminar in New Caledonia's capital, a symbol of ongoing French opposition to Maohi self-determination.

7 This section draws on interviews with former Presidents of French Polynesia Gaston Flosse (Majuro 2013) and Oscar Manutahi Temaru (Noumea 2013) and Senator Richard Tuheiava (Suva 2013).

8 'Self-determination of French Polynesia', UN General Assembly Resolution, A/67/L.56, 17 May 2013. See Maclellan (2013a).
} 
territories. France formally submitted information about New Caledonia in 2014 and 2015, but refused to submit information on French Polynesia in either year (UN General Assembly 2015).

The 2013 decision on French Polynesia came after decades of lobbying by the independence party Tavini Huiraatira. As leader of the Polynesian Liberation Front, Oscar Temaru first lobbied at the UN in 1978. He patiently sought support throughout the 1980s and 1990s, gaining solidarity from the Pacific Conference of Churches and the Nuclear Free and Independent Pacific (NFIP) movement, but little action from neighbouring Polynesian governments. ${ }^{9}$

Temaru won office as president of French Polynesia in 2004 and despite 11 changes of the presidency over a decade, continued to campaign for reinscription. In 2011, for the first time, the French Polynesian Assembly narrowly voted to support Temaru's call.

The governing Union for Democracy and Social Progress coalition (Union pour la Démocratie et le Progrès Social (UPLD)) looked to the French Socialist Party for recognition of the Maohi people's right to self-determination. The UPLD decided to soft-pedal their reinscription campaign during 2012 in order to avoid embarrassing Socialist Party candidate Francois Hollande in his successful bid for the French presidency. Once elected, however, Hollande began to back away from the interparty accord between the Socialist Party and Tavini Huiraatira.

A number of Pacific governments took up the issue of French Polynesia's self-determination at the 2011 'Engaging with the Pacific' summit, a meeting initiated by the Bainimarama regime that led to the creation of the Pacific Islands Development Forum. The 2011 summit in Nadi 'welcomed increasing social and cultural linkages between French Polynesia/Tahiti Nui and PSIDS', and 'supported the re-inscription of French Polynesia/Tahiti Nui on the UN decolonisation committee's list as the first step in the process of self-determination.' ${ }^{10}$

With Australia and France signing a Joint Statement of Strategic Partnership in January 2012, Canberra was less than enthusiastic about Temaru's reinscription initiative. In 2012, Australia's then Parliamentary Secretary for Pacific Island

\footnotetext{
9 NFIP supported publication of a booklet in English for Maohi leaders to use in lobbying Pacific governments: 'Independence and sovereignty for Te Ao Maohi / French Polynesia' (Tavini Huiraatira no Te Ao Maohi, Papeete, 1997). After the end of French nuclear testing in 1996, NFIP held its next regional conference in Tahiti in 1999. See Maclellan (1999).

10 Section 2, Final communiqué, Engaging with the Pacific leaders meeting, Tanoa hotel, Nadi, 1-2 September 2011.
} 
Affairs, Richard Marles, described France as a long-term stable democratic partner in the Pacific and reaffirmed Australian opposition to reinscription: 'We absolutely take our lead from France on this.' ${ }^{11}$

Meeting in Rarotonga in August 2012, forum leaders reiterated their support for the principle of self-determination but didn't endorse the call for reinscription. ${ }^{12}$ A month after the forum, without the restraining influence of Canberra and Wellington, the leaders of Samoa, Solomon Islands, Fiji and Vanuatu lined up at the UN General Assembly, calling for action on decolonisation.

Vanuatu's then Prime Minister Sato Kilman called on 'the independent and free nations of the world to complete the story of decolonisation and close this chapter'. He urged the UN 'not to reject the demands for French Polynesia's right to self-determination and progress' (Livtuvanu 2012).

Samoan Prime Minister Tuilaepa Sailele Malielegaoi told the general assembly: 'In the case of French Polynesia, we encourage the metropolitan power and the territory's leadership together with the support of the United Nations to find an amicable way to exercise the right of the people of the territory to determine their future' (Malielegaoi 2012).

Outside the forum, Fiji's new membership of the Non-Aligned Movement (NAM) opened the way for Foreign Minister Ratu Inoke Kubuabola to attend the 16th NAM Summit in Tehran in August 2012, which issued a new policy on French Polynesia's decolonisation: 'The Heads of State or Government affirmed the inalienable right of the people of French Polynesia-Maohi Nui to self-determination in accordance with Chapter XI of the Charter of the United Nations and the UN General Assembly resolution $1514(\mathrm{XV}) .^{\prime 13}$

Opinion was also shifting at home. The Eglise Protestante Maohi, the largest Christian denomination in French Polynesia, voted for the first time in August 2012 to support Temaru's call for reinscription. ${ }^{14}$ The following month, the Central Committee of the World Council of Churches added its voice, calling on 'France, the United Nations, and the international community to support the reinscription of French Polynesia on the UN list of countries to be decolonised, in accordance with the example of New Caledonia' (WCC Central Committee 2012; see also Bhagwan 2012).

\footnotetext{
11 Interview with Richard Marles, May 2012. See Maclellan (2012).

12 The forum communiqué simply welcomed the election of a new French government that opened fresh opportunities for a positive dialogue between French Polynesia and France on how best to realise French Polynesia's right to self-determination.' Item 70, Communiqué, 43rd Pacific Islands Forum, Rarotonga, Cook Islands, 2012.

13 Final communiqué, 16th Summit of the Non-Aligned Movement, 26-31 August 2012, Tehran, Iran.

14 'The re-inscription of Maohi Nui on this list constitutes one way to protect the people from decisions and initiatives of the French State that are contrary to their interests' (EPM 2012).
} 
With increasing regional support, the formal bid for reinscription was relaunched in early 2013, with extensive lobbying in New York by Oscar Temaru and France's then Senator for French Polynesia, Richard Ariihau Tuheiava. In January, Temaru addressed a meeting of the NAM Coordinating Bureau in New York:

This is yet another case of David against Goliath, and the reason why we want our country back on the UN's list of non-self-governing territories. Without the $\mathrm{UN}$ as a referee between France and us, this is once again an unfair and uphill battle (Temaru 2013a).

In February, the PSIDS ambassadors for Solomon Islands, Tuvalu and Nauru formally lodged a draft resolution at the UN General Assembly. France's UN Ambassador Gérard Araud lobbied hard to have the resolution delayed in the hope that it would lapse after May 2013 elections in Papeete. In the interests of compromise, the sponsoring states issued a revised version of the resolution on 1 March, but France sought for weeks to keep the resolution out of the general assembly.

In a memo to Paris, Ambassador Araud stated:

The question raised by Oscar Temaru must remain a franco-French affair, and the United Nations should not interfere with French political life, because France recognises the right of people to self-determination. France challenges the legitimacy of the Decolonisation Committee, as it has done since its creation in 1961 (Regnault 2013, p. 77).

Some UN member states were astounded by the way France pressed its case. Denouncing the 'violence and condescension' of Araud's interventions, Temaru wrote to President Hollande on $27 \mathrm{March}$, calling on him to bring the ambassador to heel:

I would draw to your attention the growing frustration and incomprehension over France's position, which we have been informed of by several UN member states ... The French pressure towards the President of the General Assembly is similarly perceived as the denial of the democracy that is at the heart of the General Assembly ... If some of your confreres in the P5 [permanent members of the Security Council] seem to be accepting the French action on our dossier, others have shared their astonishment with us (Temaru 2013b).

French Polynesia's local elections on 5 May 2013 saw the defeat of President Temaru's UPLD coalition and the return of long-serving leader Gaston Flosse (since removed from office for misuse of public funds). After his election, Flosse immediately wrote to the president of the UN General Assembly in an unsuccessful attempt to delay action on the resolution. France's ambassador boycotted the session on 17 May — but the resolution was passed without a recorded vote. 
Britain, the United States, Germany and the Netherlands all disassociated themselves from the decision. Fearful of a growing regional debate about West Papua, Indonesia's representative also stressed that the 'adoption was solely based on a specific historical context and should not be misinterpreted as precedence by other territories whose cases were pending with the Decolonisation Committee'.

\section{Regional Diplomacy and West Papua}

The diplomacy of decolonisation has bedevilled Pacific governments and regional organisations in recent years. While they have actively supported decolonisation for 'blue water' European colonies like French Polynesia, many governments have been reluctant to address struggles for self-determination in postcolonial nations such as Indonesia and PNG.

Since its founding in 1988, the MSG has actively supported the Kanak independence movement in New Caledonia. Indeed, the Front de Libération Nationale Kanak et Socialiste (Kanak and Socialist National Liberation Front (FLNKS)), rather than the Government of New Caledonia, is the full member of the sub-regional body. At the 2013 MSG summit, FLNKS spokesperson Victor Tutugoro was appointed as MSG chair, taking the role at a crucial time as the French dependency moves to a referendum on self-determination, scheduled for 2018. The MSG has also established an FLNKS unit in its Port Vila secretariat, appointing a Kanak activist as political counsellor.

In contrast to this long-standing solidarity with the FLNKS, the MSG had been largely silent on the more sensitive issue of West Papua - until now.

After more than 100,000 deaths in West Papua, there is significant popular support for West Papuan independence in the independent Melanesian nations. Even after the fall of Suharto's new order regime, there are ongoing human rights abuses by the Indonesian police and military. ${ }^{15}$ This has led to new advocacy across Melanesia, with Facebook and other social media spreading information from inside West Papua across the region. This solidarity movement has forced a complex and unresolved debate over relations with Indonesia onto the agenda of recent MSG summits.

The MSG's unity has been stressed by this debate, at a time of other trade and diplomatic disputes (Webb-Gannon and Elmslie 2014). There have been some tensions between the larger states of PNG and Fiji — which are moving closer

15 Dominic Berger says, 'Reducing political tensions and ending human rights abuses in Papua remained elusive throughout [SBY's] tenure' (Berger 2015, p. 230). 
to Jakarta - and Vanuatu and the FLNKS, which openly express solidarity with the West Papuan nationalist movement (with the Solomon Islands wavering between) (Maclellan 2015b, pp. 10-11).

Despite these rifts, the MSG's new engagement contrasts with the silence of the Pacific Islands Forum over the last decade. For nearly 30 years after its founding, the forum avoided the issue of West Papua. Action was always constrained by governments in Australia and PNG, which reaffirm the 'territorial integrity' of Indonesia and (incorrectly) state that Indonesia has always held sovereignty over West Papua. ${ }^{16}$ Trade links are growing between Canberra, Port Moresby, Suva and Jakarta, adding to other strategic concerns, such as PNG's control of its land border and Canberra's fixation with boat people.

Despite this, forum leaders could not ignore the fall of the Suharto dictatorship in 1998, Timor-Leste's independence and the organising by West Papuan nationalists that created a brief 'Papua Spring' in Jayapura at the beginning of the 21 st century. ${ }^{17}$ At the September 2000 UN Millennium Summit in New York, Nauru, Vanuatu and Tuvalu were the first countries to declare support for West Papuan self-determination at the United Nations.

Four West Papuan activists were given official delegate status at the October 2000 forum in Kiribati as members of the Nauru delegation. At the Tarawa forum, Vanuatu, Nauru and other countries supported the push for human rights in the troubled country, even as they deferred to Australian and PNG sensitivities by acknowledging Indonesia's sovereignty. Forum Chair President Teburoro Tito of Kiribati said: 'Personally, I have great sympathy for the cause of the West Papuan people, just on the basis of culture alone.' ${ }^{\prime 18}$

The forum issued an unprecedented statement calling for peaceful dialogue on the future of the country and an end to human rights abuses. At the time, Papua Presidium member FranzAlbert Joku welcomed the statement: After four decades, we are back in our natural habitat, the South Pacific.' ${ }^{19}$

Joku was looking back to earlier pan-Melanesia engagement that existed before Indonesia's 1969 Act of Free Choice. Papuan delegates Marcus Kaisiepo and Nicolas Jouwe represented Dutch New Guinea at the first South Pacific Conference in 1950. ${ }^{20}$ Dutch evangelical Christian church Reverends Kabel and

16 Australian support for Dutch sovereignty in the 1950s is discussed in Lijphart (1966).

17 For details of the Papua Spring, see Chauvel (2005).

18 Interview with President Teburoro Tito, Tarawa, September 2000. See Maclellan (2000).

19 Interview with FranzAlbert Joku, Tarawa, September 2000.

20 For photos of the West Papuans at the 1950 SPC meeting, see (DFAT 2000). 
Maloali were active at the 1961 Malua Conference of Churches and Missions in Samoa (which led to the founding of the Pacific Conference of Churches). West Papuans studied at the Fiji School of Medicine in the 1960s. ${ }^{21}$

In April 2001, the forum decided to accept Indonesia as a post-forum dialogue partner. West Papua was discussed at forum meetings between 2001 and 2003, but Indonesian repression of the Papua Spring led to an end to discussion at the forum (apart from a brief mention in the 2006 communiqué). For a decade, forum communiqués have been silent on West Papua, despite possible openings for engagement as post-Suharto presidents established a Special Autonomy Law and divided the western half of New Guinea into the two provinces of Papua and West Papua.

In recent years, the issue has shifted to the MSG, leading to unprecedented debates amongst the five MSG members. This engagement was accelerated by the decision of then MSG Chair Voreqe Bainimarama to invite Indonesia and Timor-Leste to become MSG observers at the March 2011 summit in Fiji. ${ }^{22}$

Following Fiji's 2009 suspension from forum activities, the Bainimarama regime had been extending economic and political links with Asian nations, opening an embassy in Jakarta in August 2011. Ties between Suva and Jakarta are growing, highlighted by the then Indonesian President Susilo Bambang Yudhuyono opening the 2014 Pacific Islands Development Forum and Indonesia's role in co-chairing the Multinational Observer Group for Fiji's 2014 elections. Fiji's global ambitions - including membership of the NAM and its 2013 role as chair of G77 plus China - have introduced new complexities into the regional decolonisation agenda, given Indonesia is a key player in both networks.

PNG governments have long juggled competing tensions: public sentiment in support of West Papuan rights, growing economic links with Indonesia and ASEAN, and border security along the region's only land border. PNG's policy on West Papua is complicated by concerns over its own resource-rich province of Bougainville. With the 2015 re-election of John Momis as President of the Autonomous Bougainville Government, complex debates over the reopening of the Panguna mine and a five year window before a vote on political status, Bougainville will soon pose challenges for PNG's regional leadership and the MSG.

\footnotetext{
21 Some West Papuans remained in Fiji after Indonesia's takeover. Interview with Dr Welby Korwa, Suva, 1998.

22 In February 2011, MSG foreign ministers 'endorsed applications for observership by Indonesia and Timor-Leste and agreed to seek an "out of session" decision from the leaders to allow Indonesia and TimorLeste to attend as observers at the March 2011 [MSG] leaders' summit'. (Fiji Ministry of Information press release, February 2011).
} 
Jakarta's bid for greater involvement in the MSG reflects Indonesia's mounting diplomatic efforts in the region. For many years, the Indonesian embassy in Port Moresby was the main hub for activity in forum island countries, with Indonesian officials lobbying the islands from embassies in Canberra, Wellington, Beijing and Tokyo (from 1974 until 2002, Indonesian diplomats travelled to Fiji from Wellington, until an embassy was opened in Suva).

Today, Jakarta is deploying more effort on the ground, to build economic ties but especially to counter West Papuan diplomacy. Former independence activists FranzAlbert Joku and Nick Messet now act as Indonesian diplomats and join delegations to regional and international summits, to showcase Jakarta's initiatives and argue against independence.

On the international stage, Indonesia, PNG and Fiji are all members of the UN Special Committee on Decolonisation. The two Pacific countries use the special committee as a platform to support the FLNKS, but join Indonesia in opposition to calls for West Papua to be relisted with the UN. ${ }^{23}$

In contrast, the Kanak independence coalition has long supported a fellow liberation movement in West Papua, wary of Indonesia's growing role in the MSG. Outgoing MSG chair Victor Tutugoro of the FLNKS told the author in 2015: 'For the FLNKS, the MSG is an organisation of Melanesian countries. As I see it, Indonesia is not part of the Melanesian bloc. ${ }^{24}$

Vanuatu too has long backed the West Papuan nationalist movement with practical and diplomatic aid, hosting an office for the West Papua nationalist movement. In 2011, the Sato Kilman Government briefly moved closer to Indonesia, with the signing of a Vanuatu-Indonesia Development Cooperation Agreement. These moves dismayed West Papuan activists, especially as the cooperation agreement stressed Indonesian territorial integrity and sovereignty over West Papua, and prohibited Vanuatu from interfering in Indonesia's 'internal affairs'. This decision contributed to a backlash in Port Vila and the election of a new government under Moana Carcasses Kalosil, who proceeded to launch a series of attacks on Indonesia in UN forums. ${ }^{25}$

In March 2013, the Port Vila-based West Papua National Council for Liberation (WPNCL) lodged a formal membership application to join the MSG, and the existing members began to position themselves.

\footnotetext{
23 Indonesia provided funds to Fiji for the costs of the UN Special Committee's 2014 Pacific Regional Seminar, held in Nadi. On UN policy on self-determination and the 1969 Act of Free Choice, see Saltford (2002).

24 Interview with Victor Tutugoro, Honiara, June 2015. See Maclellan (2015a).

25 In an interview (Port Vila, July 2013), incoming Justice Minister Ralph Regenvanu stressed that the West Papua issue was a central reason for public disenchantment with the Kilman Government (although many other issues contributed to its electoral defeat).
} 
In early June 2013, Fiji's Prime Minister Bainimarama held a meeting in Nadi with Djoko Suyanto, Indonesia's Coordinating Minister for Legal, Political and Security Affairs, and a former commander of Indonesia's armed forces. Soon after, to the disquiet of some delegates, Fiji arrived at the June 2013 MSG Summit in Noumea with a roadmap to drive the West Papua debate.

However, the host organisation FLNKS also formally invited the WPNCL to attend the summit. FLNKS representative Caroline Machoro-Reignier told the author:

If this issue came up today within the MSG, it's because the FLNKS requested it. We asked the representatives of West Papua to come to New Caledonia to explain the situation to us. We cannot just leave the issue aside, with all the exactions, the violations of human rights that West Papua is suffering ... However this is a very sensitive topic that affects relations between Indonesia and the other member states in the Spearhead Group. ${ }^{26}$

Indonesia sent a large delegation to press its case, including FranzAlbert Joku and Nick Messet, while a five-person delegation led by WPNCL Vice President John Otto Ondawame and Secretary-General Rex Rumakiek arrived to lobby for support of their bid for MSG membership. In a striking diplomatic gesture, PNG Prime Minister Peter O'Neill and Foreign Minister Rimbink Pato were absent from the summit, leading a large business delegation to Indonesia. Their presence in Jakarta as the MSG debated West Papua shows the priority given to relations with PNG's powerful neighbour (Maclellan 2013c).

After extensive lobbying in the corridors, MSG leaders agreed to defer a decision on the West Papua application. A decision would only be made after a delegation of Melanesian foreign ministers visited Jakarta and Jayapura and reported back to the leaders within six months (Maclellan 2013b). WPNCL's Ondawame expressed disappointment about the delay, arguing that the Indonesian government and military would stage-manage the MSG mission. However, he said he valued the opportunity to address the summit plenary and highlighted positive commitments by the MSG leaders. ${ }^{27}$

Despite these delaying tactics, the MSG summit communique included unprecedented language on West Papua, supporting 'the inalienable rights of the people of West Papua towards self-determination' and criticising 'human rights violations and other forms of atrocities relating to the West Papuan people'. ${ }^{28}$

\footnotetext{
26 Interview with Caroline Machoro-Reignier, FLNKS representative to the 2013 MSG foreign ministers meeting, Lifou, June 2013.

27 Interview with John Ondawame, Noumea, 20 June 2013. Sadly, Ondawame died in September 2014, a significant loss to the nationalist movement.

28 Final communiqué, 19th MSG leaders' summit, Escapade resort, Noumea, 20 June 2013.
} 
Indonesia then wooed Solomon Islands, with then Prime Minister Gordon Darcy Lilo travelling to Jakarta in August 2013 on a trade mission, which the Vanuatu government perceived as an effort to undercut the foreign ministers' delegation. Vanuatu later boycotted the mission to West Papua, which travelled to Jakarta and Jayapura from 11-15 January 2014, led by Fiji Foreign Minister Ratu Inoke Kubuabola. The Vanuatu government was angered by the way Indonesia transformed the trip into a trade mission and refused access to pro-independence church and civil society representatives during a brief visit to Jayapura. ${ }^{29}$

Indonesia's diplomatic efforts were rewarded at a special MSG leaders' summit in Port Moresby in June 2014, which deferred the WPNCL application for membership and agreed 'to invite all groups to form an inclusive and united umbrella group in consultation with Indonesia to work on submitting a fresh application'. ${ }^{30}$ The summit agreed on a range of activities to ensure 'that the MSG and Indonesia take a more proactive approach in addressing the issue of West Papua and Papua', broadly endorsing Indonesia's Special Autonomy Law and welcoming the involvement of West Papuans in a range of MSG sporting, cultural and development activities.

Despite this, Vanuatu continued to show its support for West Papuan selfdetermination. Vanuatu churches and customary chiefs, supported by the government, hosted a December 2014 meeting to bring together Jayapura-based activists and exiled campaigners and form a united front between competing groups. The newly created United Liberation Movement for West Papua (ULMWP) unites three strands of the West Papuan nationalist movement: the WPNCL, Federal Republic of West Papua, and the National Parliament of West Papua, which incorporates the National Committee for West Papua. In February 2015, the ULMWP resubmitted its application for full MSG membership.

In a major speech the same month, PNG Prime Minister Peter O'Neill said his country needed to do more to address human rights in West Papua. Proposing that his country take a lead in discussions with Indonesia in a mature and engaging manner', he added:

Sometimes we forgot our family, our brothers and sisters, especially those in West Papua. I think as a country the time has come for us to speak about oppression of our people. Pictures of brutality of our people appear daily on social media and yet we take no notice. We have the moral obligation to speak for those who are not allowed to talk. We must be the eyes for those who are blindfolded ( $\mathrm{O}^{\prime}$ Neill 2015).

29 Discussions with Vanuatu Foreign Minister Edward Natapei (New Caledonia, June 2013) and Prime Minister Joe Natuman (Port Vila, July 2014). The communiqué of the June 2014 Special MSG Summit noted: 'Vanuatu was of the view that the Mission's program would not allow the MSG to obtain credible information to fulfil the MSG Leaders mandate.'

30 Final communiqué, special MSG leaders' summit, PNG National Parliament, Port Moresby, June 2014. 
Indonesia continued to work to blunt the diplomatic advances of the West Papuan nationalist movement. In March 2015, during the lead up to the MSG summit, Indonesia's Foreign Minister Retno Marsudi travelled to PNG, Solomon Islands and Fiji. In May, a month before the summit, President Joko Widodo visited West Papua and PNG, announcing clemency for five political prisoners and making other concessions. ${ }^{31}$

At a press conference in Merauke, Jokowi addressed longstanding restrictions on international media travelling to West Papua: 'Starting from today, foreign journalists are allowed and free to come to Papua, just as they can [visit] other regions.' This pledge was immediately undercut by his Minister for Political, Legal and Security Affairs, Tedjo Edhy Purdijatno, who confirmed that foreign journalists would still be screened and must obtain permission from the security forces to travel to the highlands:

We'll allow it, on condition that they report on what they see, not go around looking for facts that aren't true from armed groups ... There's a lot of news out there that makes it look like [human rights] violations are taking place here all the time, but I don't think that's the case (Jakarta Globe 2015).

The diplomatic issue came to a head at the June 2015 MSG Summit in Solomon Islands, where leaders made an historic decision to expand the MSG's reach. With divergent views continuing amongst the five members, an uneasy consensus led to the granting of associate member status to Indonesia and observer status to the ULMWP.

To dodge questions over Indonesian sovereignty, the MSG leaders agreed that 'the ULMWP be admitted as an observer under the regional and international category representing Melanesians living abroad' (despite the ULMWP representing groups both inside and exiled from West Papua). In the presence of a large delegation led by Indonesian Vice Foreign Minister A.M. Fachir, the island leaders approved 'that associate membership be accorded to Indonesia representing the five Melanesian provinces in Indonesia' (Papua, West Papua, Maluku, North Maluku, and East Nusa Tenggara).

Describing the ULMWP as an 'external non-government organisation', Fiji Prime Minister Bainimarama stated:

31 Ironically, Jakarta has long argued there are no political prisoners in West Papua. Many prisoners refused presidential clemency (which requires an acknowledgement of guilt), arguing that they were falsely convicted for political reasons and that alleged acts — such as raising or displaying the Morning Star flag — were not crimes. 
Indonesian sovereignty over West Papua cannot be questioned ... the MSG has no choice but to deal with Indonesia in a positive and constructive manner. The best hope for improving the lives of the people of West Papua is to work closely with the Indonesian government, one of the most vibrant democracies in the world (Bainimarama 2015).

The 20th MSG summit communiqué noted that the 'Indonesian President is someone whom the MSG can dialogue with' ${ }^{32}$ But despite recent initiatives by President Joko Widodo, Indonesia's development policies in West Papua will continue to drive calls for change, as customary landowners fight to protect their land and restrict ongoing immigration. The future role of the five governors in MSG is unclear, given the historic difference between Papua and West Papua (which remained under Dutch administration until the 1960s) and the other three provinces (which were part of Indonesia from independence in 1949). Governors Lukas Enembe of Papua and Bram Atururi of West Papua were both absent from the 2015 summit; as they seek a different political status within Indonesia, more debate is on the cards within the MSG. ${ }^{33}$

The creation of the ULMWP as a united coalition will also pose diplomatic challenges for Pacific governments, as the MSG observer highlights historic grievances and ongoing human rights violations. ULMWP Secretary-General Octo Mote says observer status is 'a foot in the door' for dialogue between West Papuan nationalists, Melanesian governments and Indonesia: 'We're a nation in waiting, and we're not going away!'34

\section{Conclusion}

The recent flurry of diplomatic activity on decolonisation by MSG and PSIDS is a striking example of ways that new Pacific diplomatic structures have allowed action on questions that governments have been reluctant to address through the Pacific Islands Forum for many years.

Over the next five years, there will be major political and constitutional changes in two Melanesian nations, as New Caledonia and Bougainville vote on a new political status. Under the 1998 Noumea Accord, New Caledonia is scheduled to hold a referendum on self-determination in late 2018, with two other votes

32 Final communiqué, 20th MSG summit, Heritage Park Hotel, Honiara, Solomon Islands, 26 June 2015, p. 6.

33 Indonesian proposals to create even more provinces in the western half of the island of New Guinea are disrupting moves towards a strengthened autonomy law known as Otsus Plus. See IPAC (2014).

34 Interview with Octavius Mote, Honiara, June 2015. 
possible up until 2022. In a similar period, Bougainville will come to the end of its 10-15 year transition after the 2005 election of the Autonomous Bougainville Government.

These referenda have important implications for neighbours such as Australia, New Zealand and the island members of the Pacific Islands Forum and MSG. The issue of self-determination will again force itself onto the regional agenda.

\section{References}

The Australian, 1982, 'Act now before Russians move in, says Bowen', 20 February.

Bainimarama, F., 2015, 'Speech to MSG Summit Plenary Session', Honiara, 26 June.

Berger D., 2015, 'Human Rights and Yudhyono's Test of History', in E. Aspinall et al. (eds), The Yudhoyono Presidency: Indonesia's decade of stability and stagnation, Institute of South East Asian Studies, Singapore.

Bhagwan, P.J., 2012, 'The Struggle for Self-Determination', Fiji Times, 12 September.

Chauvel, R., 2005, Constructing Papuan Nationalism: History, ethnicity, and adaptation, East-West Centre, Washington.

Corbin, C., 2010, An Analysis of Implementation of the United Nations Decolonisation Mandate during the Second International Decade for the Eradication of Colonialism (2001-2010) and Strategies for Completion of the Decolonisation Mandate', Overseas Territories Report 9(5).

Department of Foreign Affairs and Trade (DFAT), 2000, The South Pacific Commission: The first fifty years, DFAT, Canberra.

Eglise Protestante Maohi (EPM), 2012, media release, August.

Fiji Ministry of Information, 2011, press release, February.

Firth, S., 2013, 'Political Status and Development: The implications for Australian foreign policy towards the Pacific Islands', SSGM discussion paper 2013/6.

Huntsman J. and K. Kelihian, 2007, The Future of Tokelau: Decolonising agendas 1975-2006, Auckland University Press, Auckland.

Institute for Policy Analysis on Conflict (IPAC), 2014, 'Papua Update: The latest on Otsus Plus', IPAC Report No. 7, 27 February. 
Jakarta Globe, 2015, 'In President's Promises on Papua, Little Sign of Meaningful Change', 10 May.

Lijphart, A., 1966, The Trauma of Decolonisation: The Dutch and West New Guinea, Yale University Press, New Haven.

Livtuvanu, M.S.K., 2012 'Statement by Prime Minister of Vanuatu', 67th Session of the UN General Assembly, New York, 28 September, p. 3.

Maclellan, N. (ed.), 1999, No Te Parau Tia, No Te Parau Mau, No Te Tiamaraa, PCRC, Suva.

Maclellan, N., 2000, 'Historical Moment for West Papua at Forum', Pacific News Bulletin, November.

Maclellan, N., 2012, 'Partenariat stratégique entre l'Australie et la France', Tahiti-Pacifique magazine, August.

Maclellan, N., 2013a, 'Hijacking Decolonisation: French Polynesia at the United Nations', Inside Story, 31 May.

Maclellan, N., 2013b, 'MSG to Send Mission to Jakarta and West Papua', Islands Business, 18 June.

Maclellan, N., 2013c, 'MSG Aims "to restructure the Pacific landscape": Summit supports Kanak and West Papuan self-determination', Islands Business, July.

Maclellan, N., 2013d, 'Forum to Discuss New Caledonia's Membership Bid', Islands Business, 4 September.

Maclellan, N., 2015a, 'FLNKS Supports West Papuan Membership Bid', Pacnews, 24 June.

Maclellan, N., 2015b, 'Competing Pressures Over West Papua', Islands Business, July.

Malielegaoi, T.S., 2012, 'Statement by Prime Minister of Samoa', 67th Session of the UN General Assembly, New York, 28 September, p. 1.

Ministry of Foreign Affairs, 2013, 'Résolution adoptée par l'Assemblée générale des Nations unies sur la Polynésie française', press release, 17 May.

Mrgudovic, N., 2008, La France dans le Pacifique sud: Les enjeux de la puissance, L'Harmattan, Paris.

O'Neill, P., 2015, 'Speech by Hon. Prime Minister Peter O'Neill CMG MP', 2015 Leaders Summit, Port Moresby, 5 February. 
Pacific Plan Review, 2013, 'Report to Pacific Leaders, Volume 1', Pacific Islands Forum Secretariat, Suva.

Regnault, J.-M., 2013, L'ONU, la France et les décolonisations tardives: l'exemple des terres françaises d'Océanie, Presses universitaires d'Aix-Marseille, Aix-en-Provence.

Saltford, J., 2002, United Nations and the Indonesian Takeover of West Papua, 1962-1969: The anatomy of a betrayal, Routledge Curzon, London.

Sarkozy, N., 2010, 'Voeux à la France d'Outre-mer', speech presented at Saint Denis de la Réunion, 19 January.

Temaru, O.M., 2013a, 'Presentation to Non Aligned Movement Coordinating Bureau meeting', New-York, January.

Temaru, O.M., 2013b, 'Réinscription de la Polynésie française sur la liste des pays non-autonome', letter from President Oscar Manutahi Temaru to President François Hollande, 27 March.

UN General Assembly, 2015, 'Information from Non-Self-Governing Territories transmitted under Article 73e of the Charter of the United Nations', Report of the Secretary General, 7 March, A/70/67.

WCC Central Committee 2012, 'Statement on Re-Inscription of French Polynesia (Maohi Nui) on UN List of Countries to be Decolonized', 4 September.

Webb-Gannon C. and J. Elmslie, 2014, 'MSG Headache, West Papuan Heartache? Indonesia's Melanesian Foray', The Asia-Pacific Journal 12(46). 
This text is taken from The New Pacific Diplomacy, edited by Greg Fry and Sandra Tarte, published 2015 by ANU Press, The Australian National University, Canberra, Australia. 